\title{
Thiosulphate Oxidation, Electron Transport and Phosphorylation in Cell-free Systems from Thiobacillus A2
}

\author{
By WEI-PING LU AND D. P. KELLY* \\ Department of Environmental Sciences, University of Warwick, Coventry CV4 7AL, U.K.
}

(Received 30 July 1982; revised 2 December 1982)

\begin{abstract}
Cell-free preparations have been made from Thiobacillus A2 that are capable of the complete oxidation of thiosulphate to sulphate and of coupling the associated electron transport to ATP synthesis with a $\mathrm{P} / \mathrm{O}$ ratio of about one. Spectrophotometric measurements and the effect of electron transport chain inhibitors on cytochrome reduction and oxygen uptake indicate that thiosulphate oxidation is coupled directly to cytochrome $c$ reduction and does not involve cytochrome $b$. Complete inhibition of phosphorylation by,2,4-dinitrophenol suggests that ATP synthesis was effected exclusively by electron transport phosphorylation accompanying reoxidation of cytochrome $c$. Enzymes for thiosulphate oxidation to sulphate and the reduction of cytochrome $c$ were located in the supernatant fraction after centrifuging at $130000 \mathrm{~g}$, but oxygen uptake required the $130000 \mathrm{~g}$ pellet fraction, which provided membrane-bound cytochrome $c$ and cytochrome oxidase.
\end{abstract}

\section{INTRODUCTION}

There have been relatively few reports of the preparation from thiobacilli of cell-free systems capable of the complete oxidation of thiosulphate to sulphate. Examples are extracts of Thiobacillus novellus (Aleem, 1965; Charles \& Suzuki, 1966; Oh \& Suzuki, 1977 a, b) and T. thiooxidans (London \& Rittenberg, 1964). Recently a membrane-associated thiosulphate-oxidizing system was obtained from $T$. novellus, but was not active on reconstitution from its constituent enzymes (Oh \& Suzuki, 1977b). Few studies have been reported of efficient electron transport phosphorylation dependent on cell-free thiosulphate oxidation. In cases where $\mathrm{P} / \mathrm{O}$ ratios of about 1.0 have been obtained it has not always been clear whether complete oxidation of thiosulphate was occurring (involving oxidation of both the reduced sulphane and oxidized sulphone atoms of the ion) or whether phosphorylation was accompanying the oxidation of sulphite derived from thiosulphate. The occurrence in some thiobacilli of substrate-level phosphorylation, dependent on APS reductase (adenylyl sulphate reductase) and ADP- or ATPsulphurylase, has probably also been an interfering factor in attempts to demonstrate oxidative phosphorylation (Ross et al., 1968; Peck, 1968; Kelly, 1978). There have in fact been no published reports of phosphorylation by cell-free extracts of thiobacilli in which the complete oxidation of thiosulphate to sulphate was simultaneously and unequivocally known to be occurring. Earlier work with T. novellus (Aleem, 1965) showed thiosulphate oxidation by crude extracts and a $144000 \mathrm{~g}$ soluble fraction with a ratio of oxygen consumed/thiosulphate oxidized of 1.6-1.8. Oxidation was stimulated by added cytochrome $c$ and recent work with Thiobacillus A2 indicated electrons from thiosulphate oxidation to enter the electron transport chain at the level of cytochrome $c$ (Kula et al., 1982). We have undertaken to prepare cell-free systems from Thiobacillus A2 that would simultaneously effect complete oxidation of thiosulphate and ATP synthesis by electron transport phosphorylation. We have sought to establish the electron transport pathway involved in thiosulphate oxidation and the subcellular location of the thiosulphateoxidizing system. 


\section{METHODS}

Organism and culture conditions. Thiosulphate-agar media were used for culture maintenance as previously described for Thiobacillus A2 (Wood \& Kelly, 1977). Continuous chemostat culture was used both for estimating maximum theoretical growth yield and as a procedure for the generation of large quantities of the organisms in a medium containing $\left(\mathrm{g} \mathrm{I}^{-1}\right): \mathrm{Na}_{2} \mathrm{~S}_{2} \mathrm{O}_{3} .5 \mathrm{H}_{2} \mathrm{O}, 12.5$ or $25 ; \mathrm{MgSO}_{4} .7 \mathrm{H}_{2} \mathrm{O}, 0.1 ; \mathrm{NH}_{4} \mathrm{Cl}, 0.8 ; \mathrm{KH}_{2} \mathrm{PO}_{4}, 1.5$; $\mathrm{Na}_{2} \mathrm{HPO}_{4} .2 \mathrm{H}_{2} \mathrm{O}, 7 \cdot 9 ; \mathrm{H}_{2} \mathrm{SO}_{4}$ as required; trace metal solution (Tuovinen \& Kelly, 1973), $10 \mathrm{ml}$. The culture was established in an LH Engineering (Slough, Bucks, U.K.) modular type series 500 fermenter with a culture volume of $750 \mathrm{ml}$, stirred (500 r.p.m.) and aerated $\left(55 \mathrm{ml} \mathrm{min}^{-1}\right)$ with air containing $1.4 \%(\mathrm{v} / \mathrm{v}) \mathrm{CO}_{2}$. Temperature was maintained at $30^{\circ} \mathrm{C}$ and $\mathrm{pH}$ at 7.7 by automatic addition of $2 \mathrm{M}-\mathrm{NaOH}$.

Preparation of crude cell-free extract. The effluent from the chemostat culture was collected in an ice-cooled vessel and kept at $4{ }^{\circ} \mathrm{C}$ until used. The bacteria were washed once with $55 \mathrm{~mm}$-phosphate buffer (pH 7.5) and resuspended $\left(20-40 \mathrm{mg}\right.$ dry $\left.\mathrm{wt}^{-1}\right)$ in the same buffer. The suspension was passed twice through a French pressure cell at $140 \mathrm{MPa}$. The disintegrated material was treated at $4{ }^{\circ} \mathrm{C}$ for $10 \mathrm{~min}$ with deoxyribonuclease $\left(2 \mu \mathrm{g} \mathrm{ml}^{-1}\right)$ and $10 \mathrm{mM}^{-\mathrm{MgCl}_{2}}$, then centrifuged at $10000 \mathrm{~g}$ for $15 \mathrm{~min}$ at $4{ }^{\circ} \mathrm{C}$ to remove any unbroken cells. The supernatant fraction was used as the crude extract.

Alternatively a crude extract was prepared with a lysozyme treatment based on the method described by Kaback (1971). Washed cells were suspended to a final $15 \mathrm{mg}$ dry wt $\mathrm{ml}^{-1}$ in $0.5 \mathrm{M}$-sucrose containing $100 \mathrm{~mm}$ EDTA and $10 \mathrm{~mm}$-phosphate buffer $(\mathrm{pH} 7)$. Lysozyme was added to the suspension at a concentration of $1 \mathrm{mg} \mathrm{m}^{-1}$, then incubated at $30^{\circ} \mathrm{C}$ for $20-30 \mathrm{~min}$ until the absorbance at $440 \mathrm{~nm}$ of a diluted aliquot of the suspension had decreased 5- to 6-fold compared with that before addition of lysozyme. The lysozyme-treated cells were sedimented by centrifugation at $12000 \mathrm{~g}$ for $15 \mathrm{~min}$ and resuspended to one-fifth of the original volume in 55 mM-phosphate buffer ( $\mathrm{pH} 7 \cdot 5$ ). The suspension was then diluted 5-10-fold with water to disrupt the cells. The resulting suspension had a high viscosity which was rapidly lowered by adding deoxyribonuclease $(10 \mu \mathrm{g} \mathrm{ml}-1)$ and $\mathrm{MgCl}_{2}(2 \mathrm{mM})$. The suspension was then centrifuged at $5000 \mathrm{~g}$ for $30 \mathrm{~min}$ to remove any unbroken cells. The supernatant was also termed the crude cell-free extract.

Preparation of 'membrane fraction'. The extract from either French pressure cell or lysozyme treatment was centrifuged at $48000 \mathrm{~g}$ or $130000 \mathrm{~g}$ for $45 \mathrm{~min}$ or $90 \mathrm{~min}$ at $4{ }^{\circ} \mathrm{C}$. The pellet fraction was washed with a 20 -fold volume of $55 \mathrm{~mm}$-phosphate buffer $(\mathrm{pH} 7.5)$ and recentrifuged. The particulate fraction, containing cell membrane particles, was resuspended in the same buffer to give $8-15 \mathrm{mg}$ protein $\mathrm{ml}^{-1}$.

Preparation of 'soluble fraction'. The extract from lysozyme treatment was centrifuged at $48000 \mathrm{~g}$ for $30 \mathrm{~min}$ and the supernatant further spun at $130000 \mathrm{~g}$ for $90 \mathrm{~min}$. The resultant supernatant was carefully removed and designated 'soluble fraction'. The supernatant $(130000 \mathrm{~g})$ from French pressure cell treatment was not exclusively a 'soluble fraction' as it contained membrane material (see Results).

Enzyme assays. The thiosulphate-oxidizing activity was routinely assayed at $30^{\circ} \mathrm{C}$ by measuring oxygen consumption in a Teflon-covered Clark oxygen electrode cell (Rank Brothers, Bottisham, U.K.) with a chart recorder. Oxygen concentration in the experimental system was calibrated using the method described by Robinson \& Cooper (1970). The reaction mixture (final volume, $1 \mathrm{ml}$ ) contained, unless otherwise specified, $2 \mu \mathrm{mol}$ thiosulphate; $50 \mu \mathrm{mol}$ phosphate buffer (pH 7.5); 0.2 or $0.5 \mathrm{mg}$ dry wt cells or $5 \mathrm{mg}$ enzyme protein. The reaction was started by injecting thiosulphate solution with a Hamilton microsyringe. Activity was expressed as $\mathrm{nmol}$ or $\mu \mathrm{mol}$ oxygen uptake $\min ^{-1}(\mathrm{mg} \text { protein })^{-1}$ or (mg dry wt $)^{-1}$.

The NADH-, succinate- or sulphite-oxidizing activities were measured polarographically in the same way as above except that $0.2 \mu \mathrm{mol} \mathrm{NADH}, 0.5 \mu \mathrm{mol}$ succinate or $1 \mu \mathrm{mol} \mathrm{Na} \mathrm{NO}_{3}$ in $5 \mathrm{~mm}$-EDTA was used instead of thiosulphate.

Rhodanese activity was measured by a method based on that of Silver \& Kelly (1976). The reaction mixture contained $50 \mu \mathrm{mol} \mathrm{Na} \mathrm{S}_{2} \mathrm{O}_{3}, 125 \mu \mathrm{mol}$ Tris $(\mathrm{pH} \mathrm{10 \cdot 6}) ; 100 \mu \mathrm{mol} \mathrm{KCN}$; enzyme and water to give $2 \cdot 1 \mathrm{ml}$. After incubation for $10 \mathrm{~min}$ at $30^{\circ} \mathrm{C}$, thiocyanate was determined as described previously (Wood \& Kelly, 1981). For the assay of small quantities of cells, the organisms were lysed by the modified EDTA-lysozyme method of Vandenbergh et al. (1979). Lysozyme and EDTA (final concentrations $0.5 \mathrm{mg} \mathrm{ml}^{-1}$ and $10 \mathrm{mM}$, respectively) were added to the cell suspension (final concentration about $1 \mathrm{mg}$ dry wt $\mathrm{ml}^{-1}$ ), which was then incubated at $30^{\circ} \mathrm{C}$ for 20-30 min until the turbid cell mixtures became clear and some precipitation occurred. The lysed cell suspension was used to assay rhodanese activity as described above. Alternatively the cells were incubated with $5 \%(\mathrm{v} / \mathrm{v})$ Triton $\mathrm{X}-100$ for $20 \mathrm{~min}$ at room temperature and then the rhodanese activity was measured. The rhodanese activities measured by either method were similar.

Thiosulphate: cytochrome $c$ oxidoreductase activity was measured by following the reduction of cytochrome $c$ (horse heart III) at $550 \mathrm{~nm}$ in $1 \mathrm{~cm}$ cuvettes with a Pye-Unicam SP1700 spectrophotometer. The assay mixture contained, unless otherwise stated, $2 \mu \mathrm{mol} \mathrm{Na} \mathrm{N}_{2} \mathrm{~S}_{3}, 50 \mu \mathrm{mol}$ phosphate buffer (pH 7.5); 35 or 70 nmol cytochrome $c ; 3 \mathrm{mg}$ protein and water to give a final volume of $1 \mathrm{ml}$. The same procedure was employed to assay sulphite : cytochrome $c$ oxidoreductase activity, except that $2 \mu \mathrm{mol}$ sulphite in $5 \mathrm{~mm}$-EDTA, $100 \mu \mathrm{mol}$ Tris/ $\mathrm{HCl}$ $(\mathrm{pH} 7.5)$ and $0.5 \mathrm{mg}$ protein were used instead of thiosulphate and phosphate. Activity was expressed as nmol 
cytochrome $c$ reduced $\min ^{-1}(\mathrm{mg} \text { protein })^{-1}$; a millimolar extinction coefficient at $550 \mathrm{~nm}$ of $28 \cdot 0$ was used.

Spectrophotometry. Difference spectra were obtained with Pye-Unicam SP1700 or SP1800 recording spectrophotometers. Experimental details are provided in the legends to figures.

Oxidative phosphorylation. Reaction mixtures were incubated at $30^{\circ} \mathrm{C}$ in the oxygen electrode cell as described above. The assay mixture contained, in a total volume of $1.0 \mathrm{ml}(\mu \mathrm{mol}): 40$ phosphate buffer $(\mathrm{pH} 7 \cdot 5) ; 1$ AMP; $1 \mathrm{ADP} ; 20 \mathrm{NaF}$ (to inhibit endogenous ATPase activity); $6 \mathrm{MgCl}_{2} ; 10 \mathrm{Na}_{2} \mathrm{~S}_{2} \mathrm{O}_{3} ;$ and cell-free extract $(3 \mathrm{mg}$ protein). NADH $(0 \cdot 2 \mu \mathrm{mol})$ was added instead of thiosulphate when NADH was used as substrate. The reaction was started by adding substrate with a microsyringe. The rate of oxygen uptake was recorded throughout the reaction. To terminate the reaction, $0.5 \mathrm{ml}$ assay mixture was removed quickly into a tube containing $0.4 \mathrm{ml} 3 \%$ (w/v) perchloric acid, to which $0.1 \mathrm{ml} 2.6 \mathrm{M}-\mathrm{NaOH}$ was added shortly afterwards. The amount of ATP in the neutralized reaction mixture was determined by a luciferin-luciferase method using a Lumac celltester M1030 (Boro Labs Ltd, U.K.). Endogenous respiration and ATP formation by controls were determined by the same procedure except that the substrate was omitted.

Analytical procedures. Thiosulphate was estimated colorimetrically as described by Kelly et al. (1969) or by Sörbo (1957). Biomass was estimated from absorbance at $440 \mathrm{~nm}(1 \mathrm{~cm})$ using appropriate dry weight-absorbance calibration curves. Direct determination of dry weight of organisms in culture confirmed that this was a reliable method for monitoring biomass concentration. Protein was estimated by the Lowry procedure, using crystalline bovine serum albumin as standard. Carbon content of dried bacteria and cultures was determined with a Beckman Total Organic Carbon Analyzer.

Chemicals. Lysozyme (egg white), cytochrome $c$ (horse heart III), cytochrome oxidase (bovine heart), rhodanese (bovine liver), catalase (bovine liver), bovine serum albumin, NADH, antimycin A, HQNO and rotenone were from Sigma. Luciferin-luciferase and ATP were purchased from Boro Labs Ltd, U.K.; ADP from Boehringer Mannheim; and deoxyribonuclease (bovine) from Seravac Lab., U.K.

\section{RESULTS}

\section{Aerobic thiosulphate-limited chemostat culture}

A continuous culture was established using a medium containing approximately $30 \mathrm{~mm}$-thiosulphate. Steady states were maintained at eight dilution rates $(D)$ between 0.024 and $0.084 \mathrm{~h}^{-1}$ (Fig. 1), during which no thiosulphate was detectable in the cultures. Complete oxidation of thiosulphate occurred in all steady states in agreement with the following equation:

$$
\mathrm{S}_{2} \mathrm{O}_{3}^{2-}+2 \mathrm{O}_{2} \rightarrow 2 \mathrm{SO}_{4}^{2-}+2 \mathrm{H}^{+}
$$

Precise determination of input concentration of thiosulphate and biomass enabled estimation of steady-state yield in terms of $\mathrm{g}$ dry wt (mol thiosulphate consumed) ${ }^{-1}$ for each dilution rate.
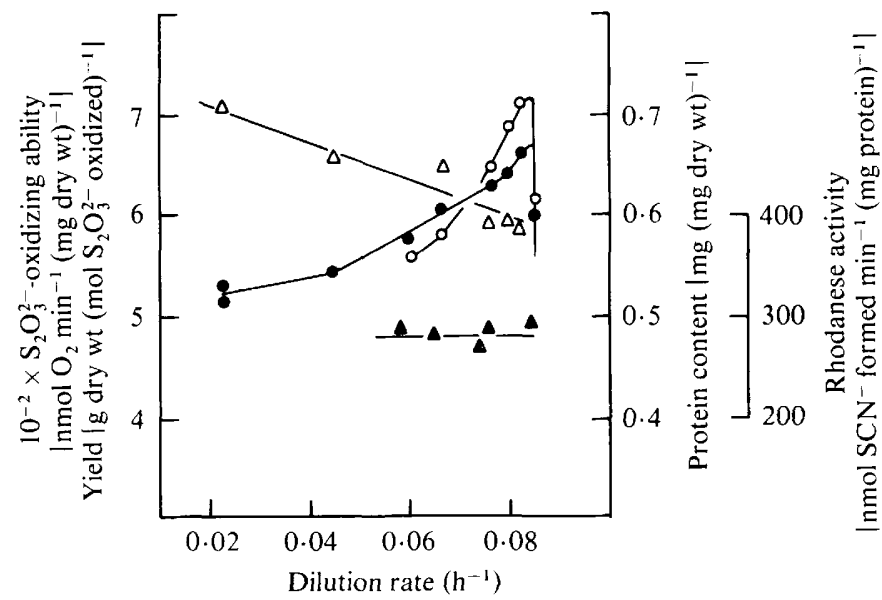

Fig. 1. Steady-state yield, thiosulphate oxidation rate, protein content and rhodanese activity of a thiosulphate-limited chemostat of Thiobacillus A2. Yield; $O$, rate of oxidation of thiosulphate by organisms removed from the chemostat and assayed polarographically; $\triangle$, protein content of the organisms; $\mathbf{\Lambda}$, rhodanese activity in lysozyme-treated organisms. 


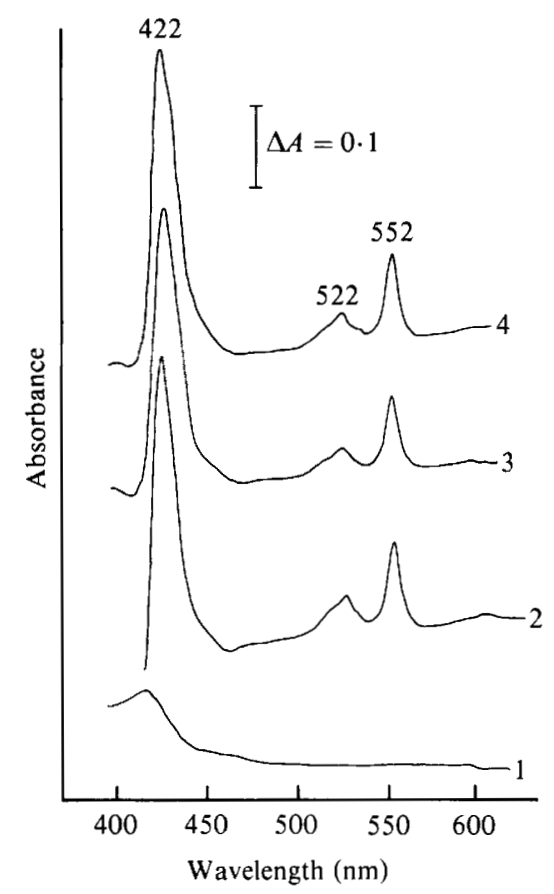

Fig. 2. Difference spectra of Thiobacillus A2 crude extract $\left(6 \mathrm{mg}\right.$ protein $\left.\mathrm{ml}^{-1}\right)$ incubated without further additions (trace 1); with $1 \mathrm{mM}-\mathrm{NADH}$ or $5 \mathrm{mM}$-succinate (trace 2); with $10 \mathrm{mM}$-thiosulphate or sulphite (trace 3); with $10 \mathrm{mM}$-thiosulphate plus either rotenone, antimycin A $\left(50 \mu \mathrm{g} \mathrm{ml}^{-1}\right)$ or HQNO $\left(25 \mu \mathrm{g} \mathrm{ml}^{-1}\right)$ (trace 4$)$.

Viability of the organisms in steady states was high $(>90 \%)$ at all $D$ values tested. The yield increased from $5.35 \mathrm{~g} \mathrm{dry} \mathrm{wt}$ (mol thiosulphate consumed) ${ }^{-1}$ at $D=0.024 \mathrm{~h}^{-1}$ to 6.66 at $D=$ $0.081 \mathrm{~h}^{-1}$ (Fig. 1). $D_{\text {crit }}$ (above which washout would occur) was approximately $0.085 \mathrm{~h}^{-1}$. The specific rate of thiosulphate oxidation $\left[q_{\mathrm{S}_{2} \mathrm{O}_{3}^{2-}}=\mathrm{mmol} \mathrm{h}^{-1}(\mathrm{~g} \text { dry wt})^{-1}\right]$ in the steady state was calculated for each dilution rate from thiosulphate consumption rate and the steady-state biomass. The value of $q_{\mathrm{S}_{2} \mathrm{O}_{3}^{2}}$ increased from 4.58 at $D=0.025 \mathrm{~h}^{-1}$ to 14.01 at $D=0.084 \mathrm{~h}^{-1}$ and gave a linear relationship (fitted by regression analysis when plotted against $D$. The correlation coefficient for fit of the eight data points to a straight line was 1.003. The reciprocal of the slope of this plot indicated a maximum theoretical growth yield $\left(Y^{\max }\right)$ of $7.04 \mathrm{~g}$ dry wt (mol thiosulphate $)^{-1}$. The $q$ intercept of the plot gave a maintenance coefficient $(m)$ of $1.44 \mathrm{mmol}$ thiosulphate $\mathrm{h}^{-1}$ (g dry wt) $)^{-1}$.

The protein content of the bacteria decreased as the dilution rate increased, but the capacity to oxidize thiosulphate measured in the oxygen electrode cell $\left[\mathrm{nmol} \mathrm{O}_{2} \mathrm{~min}^{-1}\left(\mathrm{mg}\right.\right.$ dry wt) ${ }^{-1}$, increased with increased $D$. The carbon content of the bacteria was $46 \%(\mathrm{w} / \mathrm{w})$ of the dry wt. The specific activity of rhodanese was constant at $280 \pm 10 \mathrm{nmol} \mathrm{min}^{-1}$ (mg protein)-1 at all dilution rates tested (Fig. 1).

Thiosulphate oxidation and the electron transport chain in thiosulphate-grown Thiobacillus A2

Whole cells oxidized thiosulphate rapidly, but did not oxidize succinate. Sulphite was oxidized by whole cells at about $15 \%$ of the rate of thiosulphate in $0.1 \mathrm{M}$-Tris/ $\mathrm{HCl}$ buffer but only at less than $5 \%$ of the thiosulphate rate in phosphate buffer. Crude extracts oxidized thiosulphate, NADH and succinate but showed only very slight ability to oxidize sulphite or formate when assayed in the oxygen electrode. Thiosulphate was oxidized at similar rates by crude extracts $\left(10 \mathrm{mg}\right.$ protein $\left.\mathrm{ml}^{-1}\right)$ in Tris $(0.01-0.1 \mathrm{M})$ or phosphate $(0.03-0.1 \mathrm{M})$ buffers. The reduced minus oxidized spectra of the crude extract, membrane fraction and soluble fraction, using $\mathrm{NADH}$, succinate, $\mathrm{S}_{2} \mathrm{O}_{3}^{2-}$ or $\mathrm{SO}_{3}^{2-}$ as reductants, indicated that cytochromes $c, b$ and $a$ 


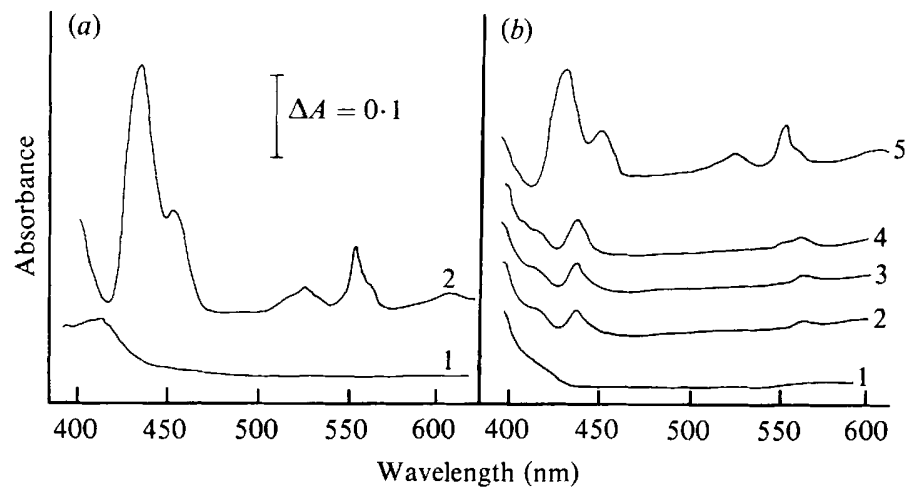

Fig. 3. Cytochrome reduction in Thiobacillus A2 membrane fraction and the effect of electron transport inhibitors. (a) Difference spectra immediately after addition to membrane fraction $(7.5 \mathrm{mg}$ protein) of $10 \mathrm{~mm}$-thiosulphate or sulphite (trace 1 ), or $1 \mathrm{~mm}-\mathrm{NADH}$ or $5 \mathrm{~mm}$-succinate (trace 2). Prolonged incubation did not alter trace 1. (b) Cytochrome reduction using membrane fraction $(5 \mathrm{mg}$ protein) with $\mathrm{NADH}$ or succinate after $2 \mathrm{~min}$ pre-incubation with either antimycin $\mathrm{A}\left(50 \mu \mathrm{g} \mathrm{ml}^{-1}\right)$ or HQNO $\left(25 \mu \mathrm{g} \mathrm{ml}^{-1}\right)$, measured after $0 \mathrm{~min}$ (trace 1$), 2 \mathrm{~min}$ (trace 2), $8 \mathrm{~min}$ (trace 3 ), 9 min (trace 4), $10 \cdot 5 \mathrm{~min}$ (trace 5 ).

were present in Thiobacillus A2 with $\alpha$ bands at 552, 560 and 605-620 nm respectively (Figs 2, 3). A trough at $450 \mathrm{~nm}$ suggested that flavin-protein was also present.

The cytochromes were reduced immediately on addition of NADH or succinate to the crude extract or membrane fraction. The cytochrome $b$ band at $560 \mathrm{~nm}$ was visible in the membrane fraction (Fig. 3) but was masked by the very high concentration of cytochrome $c$ in the crude extract [approximately $1.4 \mathrm{nmol}(\mathrm{mg} \text { protein })^{-1}$ ]. With thiosulphate or sulphite as reductants, the spectra of the crude extract appeared in 5-15 min during which the reaction mixture in the cuvette apparently became anaerobic since the peaks would disappear if oxygen was introduced simply by inverting the cuvettes, indicating high activity of cytochrome oxidase in the crude extract. Reoxidation did not occur with NADH or succinate as reductants because the oxidation rates of NADH or succinate in the crude extract were about 15 and 5 times higher, respectively, than that of thiosulphate. Cytochrome $c_{552}$ reduced in the soluble fraction by thiosulphate could not be oxidized by adding mammalian cytochrome oxidase. Horse heart cytochrome $c$ reduced by thiosulphate in the soluble fraction could easily be oxidized by the membrane fraction.

The difference spectra in the soluble fraction were formed as soon as thiosulphate or sulphite was added (Fig. 4). This fraction probably contained only $c$-type cytochrome ( $\alpha$ band at $552 \mathrm{~nm}$ ). Thiosulphate or sulphite failed to reduce the cytochromes in the membrane fraction (Fig. 3). Similarly NADH or succinate did not reduce cytochromes in the soluble fraction (Fig. 4).

Antimycin A or HQNO inhibited the reduction of cytochrome $c$ with NADH or succinate as reductants but had no effect with thiosulphate or sulphite as substrates (Figs 2 and $3 b$ ).

The effects of several inhibitors on NADH, succinate or thiosulphate oxidation by the crude extract are shown in Table 1. The results confirmed the finding from the difference spectra that neither $b$-type cytochrome nor any electron transport chain component on the NADH dehydrogenase side of cytochrome $b$ was involved in the oxidation of thiosulphate by oxygen.

\section{Stoicheiometry of thiosulphate oxidation by cell-free extracts}

Thiosulphate oxidation by whole cells or cell-free extract was consistent with equation (1), two molecules of oxygen being consumed for each thiosulphate oxidized (Table 2).

Neither the soluble nor the membrane fraction (from centrifuging at $130000 \mathrm{~g}$ ) could separately carry out the oxidation, indicating that factors present in both fractions were necessary (Table 2). NADH- or succinate-oxidizing activities were, however, mainly membrane bound, hardly any activity being found with the soluble fraction alone. 


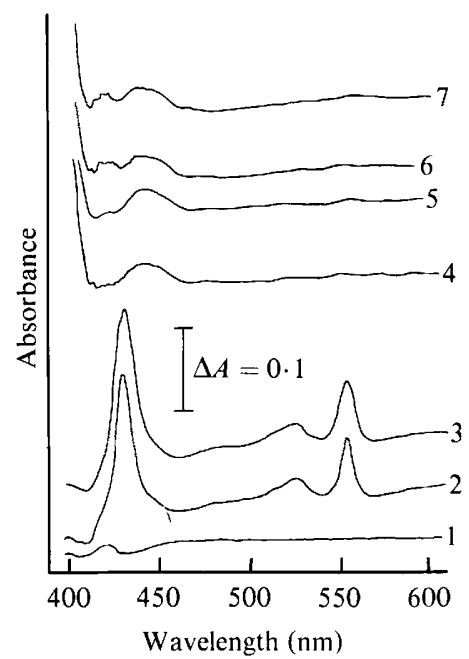

Fig. 4. Difference spectra of the 'soluble fraction' ( $5 \mathrm{mg}$ protein) from Thiobacillus A2 incubated with no further addition (trace 1), $10 \mathrm{~mm}$-thiosulphate or sulphite for 1 and $4 \mathrm{~min}$ (traces 2 and 3), $1 \mathrm{~mm}-\mathrm{NADH}$ or $5 \mathrm{~mm}$-succinate for 2, 5,8 and $25 \mathrm{~min}$ (traces $4,5,6$ and 7 ).

Table 1. Effect of electron transport inhibitors on the oxidation of NADH, succinate and thiosulphate by a crude extract of Thiobacillus $A 2$

Initial oxidation rates were determined using the oxygen electrode cell ( $1 \mathrm{ml}$ final volume) as described in Methods. Inhibitors were added after the initial rates of substrate oxidation had been established.

\begin{tabular}{lll} 
Substrate & \multicolumn{1}{c}{ Inhibitor } & $\begin{array}{c}\text { Inhibition of } \\
\text { oxidation rate }(\%)\end{array}$ \\
$\mathrm{NADH}$ & Antimycin A $(10 \mu \mathrm{g})$ & 96 \\
& HQNO $(5 \mu \mathrm{g})$ & 97 \\
& Rotenone $(10 \mu \mathrm{g})$ & 93 \\
Succinate & Antimycin A $(10 \mu \mathrm{g})$ & 75 \\
& HQNO $(5 \mu \mathrm{g})$ & 80 \\
$\mathrm{Na}_{2} \mathrm{~S}_{2} \mathrm{O}_{3}$ & Antimycin A $(10 \mu \mathrm{g})$ & 13 \\
& HQNO $(5 \mu \mathrm{g})$ & 11 \\
& Rotenone $(10 \mu \mathrm{g})$ & 10 \\
& Cyanide $(0 \cdot 1 \mathrm{mM})$ & 95
\end{tabular}

Cytochrome $c$ (horse heart III) caused little stimulation of the activity of thiosulphate oxidation by the crude extract which was, however, slightly inhibited $(30 \%)$ by reduced glutathione $(5 \mathrm{~mm})$ and strongly $(80 \%)$ by sulphite $(2 \mathrm{mM})$ if the sulphite was added before thiosulphate.

The crude extract exhibited a high affinity for thiosulphate, with a $K_{\mathrm{m}}$ value between $33 \mu \mathrm{M}$ and $90 \mu \mathrm{M}$ (e.g. Fig. 5) compared to $37 \mu \mathrm{M}$ for thiosulphate-dependent oxygen uptake by whole cells, even though the $V_{\max }$ for thiosulphate oxidation by the crude extract was approximately one-hundredth of that for whole cells. It was very difficult to measure the $K_{\mathrm{m}}$ value precisely for the crude extract because (a) there was a lag and acceleration phase of several minutes before the maximum rate of oxidation was reached; and (b) the specific activity of thiosulphate oxidation was related to the concentration of extract (Fig. $6 a$ ), thus the specific activity was increased with increase of protein concentration up to $12 \mathrm{mg} \mathrm{ml}^{-1}$, indicating that a complex enzyme system was involved in thiosulphate oxidation. There was also an interdependence of Tris buffer concentration and protein concentration in determining the specific activity of thiosulphate oxidation (Fig. 6b). 


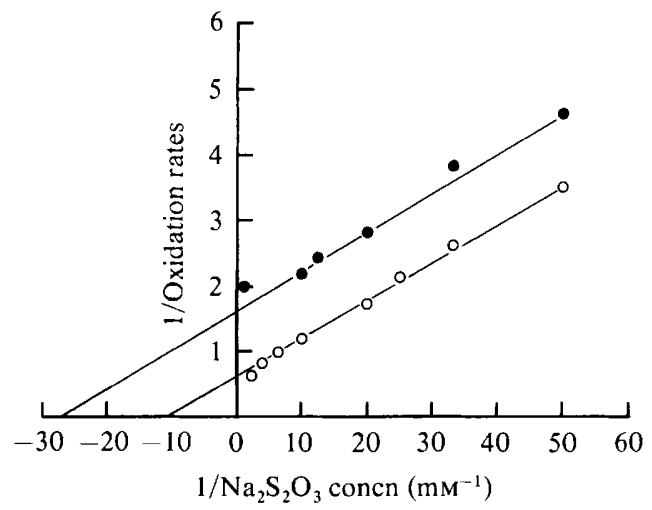

Fig. 5. Kinetics of oxidation of thiosulphate by intact organisms $(0.9 \mathrm{mg}$ dry wt; $)$ and crude extract $(9.5 \mathrm{mg}$ protein; $O)$ of Thiobacillus A2 using the oxygen electrode. Lineweaver-Burk plots of reciprocals of thiosulphate concentrations $(20-400 \mu \mathrm{M})$ and oxygen uptake rate $\left(\mu \mathrm{mol} \mathrm{min} \mathrm{m}^{-1}\right.$ for intact organisms and nmol $\times 10^{-2} \mathrm{~min}^{-1}$ for crude extract) are shown. $K_{\mathrm{m}}$ and $V_{\max }$ values were calculated as

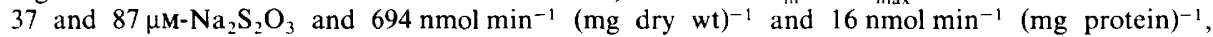
respectively.

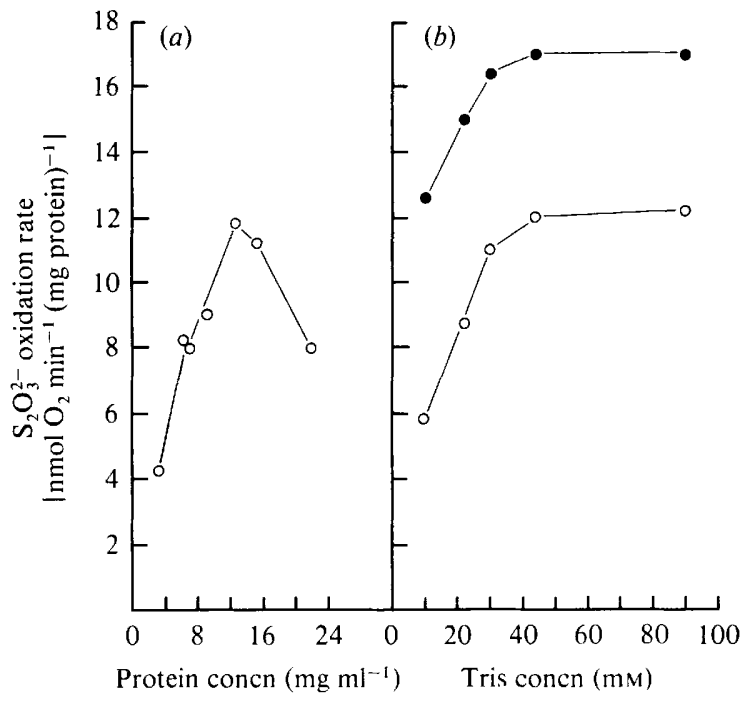

Fig. 6. Thiosulphate oxidation by crude extracts of Thiobacillus A2. (a) Effect of concentration of crude extract on specific activity of thiosulphate oxidation; $(b)$ effect of concentration of Tris/ $\mathrm{HCl}$ buffer, $\mathrm{pH} 7 \cdot 4$, on specific activity with two amounts of crude extract $\left(5 \mathrm{mg}\right.$ protein $\mathrm{ml}^{-1}, 0 ; 10 \mathrm{mg}$ protein $\left.\mathrm{ml}^{-1}, \mathrm{O}\right)$. Oxygen uptake was determined polarographically as described in Methods.

\section{Reconstitution and localization of the thiosulphate oxidation system}

Table 3 shows that the factors essential for thiosulphate oxidation were totally soluble in the cell and that the membrane fraction was only necessary for the terminal transfer of electrons to oxygen. The membrane fraction could be replaced by mammalian cytochrome $c$ and cytochrome oxidase. The stoicheiometry of thiosulphate oxidation by the reconstituted system also showed an $\mathrm{O}_{2} / \mathrm{S}_{2} \mathrm{O}_{3}^{2-}$ ratio of 2 , which suggested that the reaction was complete (equation 1 ).

ATP formation by cell-free preparations during thiosulphate oxidation

The oxidation of thiosulphate was coupled to ATP synthesis by the $40000 \mathrm{~g}$ supernatant fraction from Thiobacillus A2 (Table 4). The $\mathrm{P} / \mathrm{O}$ ratio from four determinations was $1 \cdot 10 \pm$ 
Table 2. Thiosulphate oxidation by whole cells and extracts of Thiobacillus $A 2$

Thiosulphate oxidation was measured polarographically as described in Methods. Residual thiosulphate was determined by the method of Sörbo (1957).

\begin{tabular}{|c|c|c|c|c|}
\hline $\begin{array}{l}\text { Reaction system } \\
\text { (mg protein) }\end{array}$ & $\begin{array}{c}\text { Total } \\
\text { incubation } \\
\text { time } \\
\text { (min) }\end{array}$ & $\begin{array}{c}\mathrm{Na}_{2} \mathrm{~S}_{2} \mathrm{O}_{3} \\
\text { oxidized } \\
(\mu \mathrm{mol})\end{array}$ & $\begin{array}{c}\mathrm{O}_{2} \\
\text { consumed } \\
(\mu \mathrm{mol})\end{array}$ & $\mathrm{O}_{2} / \mathrm{Na}_{2} \mathrm{~S}_{2} \mathrm{O}_{3}$ \\
\hline ells $(0.55 \mathrm{mg}$ dry wt) & $4 \cdot 5$ & $0 \cdot 58$ & 1.08 & $1 \cdot 86$ \\
\hline$x \operatorname{tract}(10)^{*}$ & 8 & 0.46 & 0.92 & $2 \cdot 00$ \\
\hline$x \operatorname{tract}(12 \cdot 5) \dagger$ & 16 & 0.81 & $1 \cdot 76$ & $2 \cdot 17$ \\
\hline fraction' $(7) \dagger$ & 15 & 0 & 0 & - \\
\hline ane fraction' $(3) \dagger$ & 15 & 0 & 0 & - \\
\hline$(5 \cdot 6)+$ 'Membrane' $(0 \cdot 6)$ & 15 & 0.66 & $1 \cdot 31$ & 1.98 \\
\hline
\end{tabular}

* Prepared using the French pressure cell.

$\dagger$ Prepared using lysozyme treatment for crude extract.

Table 3. Thiosulphate oxidation by the 'soluble fraction' ( $7 \mathrm{mg}$ protein) of Thiobacillus $A 2$ supplemented with horse heart cytochrome $c(0.17 \mu \mathrm{mol})$ and bovine cytochrome oxidase (5 units)

Experimental conditions were as described in Methods, except that oxygen uptake was recorded until thiosulphate oxidation was complete.

$\begin{array}{ccc}\begin{array}{c}\mathrm{Na}_{2} \mathrm{~S}_{2} \mathrm{O}_{3} \text { added } \\ (\mathrm{nmol})\end{array} & \begin{array}{c}\mathrm{O}_{2} \text { consumed } \\ \text { (nmol) }\end{array} & \mathrm{O}_{2} / \mathrm{Na}_{2} \mathrm{~S}_{2} \mathrm{O}_{3} \\ 20 & 40 \cdot 3 & 2.02 \\ 50 & 99 \cdot 5 & 1.99 \\ 200 & 385.0 & 1.93\end{array}$

Table 4. Oxidative phosphorylation by cell-free extracts of Thiobacillus A2

Experimental conditions were as described in Methods, using extracts prepared from French pressure cell treatment. Values for ATP formation and oxygen consumption were corrected for values obtained without added substrate.

\begin{tabular}{|c|c|c|c|c|c|c|}
\hline $\begin{array}{l}\text { Preparation } \\
\text { tested* }\end{array}$ & Substrate & $\begin{array}{l}\text { Reaction } \\
\text { time } \\
(\mathrm{min})\end{array}$ & $\begin{array}{c}\text { Inhibitor } \\
\left(\mu \mathrm{g}(\mathrm{mg} \text { protein })^{-1}\right)\end{array}$ & $\begin{array}{c}\text { ATP } \\
\text { formed } \\
(\mathrm{nmol})\end{array}$ & $\begin{array}{l}\text { Oxygen } \\
\text { consumed } \\
\text { (natom) }\end{array}$ & $\mathrm{P} / \mathrm{O}$ \\
\hline \multirow[t]{2}{*}{$S-40000$} & $\mathrm{Na}_{2} \mathrm{~S}_{2} \mathrm{O}_{3}$ & 6 & $\begin{array}{l}\text { None } \\
\text { Antimycin A (2) } \\
\text { HQNO (2) }\end{array}$ & $\begin{array}{l}231 \\
189 \\
227\end{array}$ & $\begin{array}{l}258 \\
210 \\
241\end{array}$ & $\begin{array}{l}1 \cdot 12 \\
1 \cdot 11 \\
1 \cdot 06\end{array}$ \\
\hline & $\mathrm{NADH}$ & 0.5 & $\begin{array}{l}\text { None } \\
\text { Antimycin A (2) } \\
\text { HQNO (2) }\end{array}$ & $\begin{array}{r}322 \\
12 \\
10\end{array}$ & $\begin{array}{r}167 \\
0 \\
0\end{array}$ & $\begin{array}{l}0.52 \\
- \\
-\end{array}$ \\
\hline S- 130000 & $\mathrm{Na}_{2} \mathrm{~S}_{2} \mathrm{O}_{3}$ & 4 & $\begin{array}{l}\text { None } \\
\text { 2,4-Dinitrophenol }(0 \cdot 1 \mathrm{~mm})\end{array}$ & $\begin{array}{r}104 \\
0\end{array}$ & $\begin{array}{r}80 \\
113\end{array}$ & $\begin{array}{c}0 \cdot 76 \\
-\end{array}$ \\
\hline
\end{tabular}

* S-40000, supernatant fraction from centrifuging at $40000 \mathrm{~g}$ for $30 \mathrm{~min}$; S-130000, supernatant fraction from centrifuging at $130000 \mathrm{~g}$ for $90 \mathrm{~min}$.

0.23. This oxidative phosphorylation was not affected by antimycin A or HQNO, in contrast to NADH-dependent oxidative phosphorylation which was severely inhibited (Table 4). This confirmed the former finding that thiosulphate entered the electron transport chain at the cytochrome $c$ level and only the terminal site of energy conservation involving the action of cytochrome $c$ :cytochrome oxidase was functional in thiosulphate-grown Thiobacillus A2. 
The crude extract $(10000 \mathrm{~g}$ or $20000 \mathrm{~g}$ supernatant) oxidized thiosulphate less rapidly and exhibited phosphorylation but with a wide variation in $\mathrm{P} / \mathrm{O}$ ratio (from 0.5 to 1.5 ).

The $130000 \mathrm{~g}$ supernatant from organisms treated in a French pressure cell also catalysed phosphorylation coupled to thiosulphate oxidation (Table 4). The same kind of supernatant from lysozyme-treated cells failed to oxidize thiosulphate (Table 2). The French pressure cell preparation contained cytochrome oxidase activity and was able to oxidize NADH. These results indicate that membrane material was still present in the $130000 \mathrm{~g}$ supernatant liquid, as was also shown by Loya et al. (1982). Lysozyme treatment presumably produced no membrane material not sedimented at $130000 \mathrm{~g}$.

AMP was added to the reaction mixture in order to inhibit the adenylate kinase in the crude extract, which otherwise rapidly catalysed the conversion of about one-third of the added ADP into ATP. ATPase activity was also observed in the crude extract in the absence of fluoride, with an initial hydrolysis rate of approximately $10 \mathrm{nmol} \mathrm{ATP} \mathrm{min}^{-1}(\mathrm{mg} \text { protein })^{-1}$.

\section{Occurrence of rhodanese in extracts}

Most rhodanese activity was recovered in the soluble fractions following lysozyme treatment, indicating it not to be membrane-bound. If bovine liver rhodanese $\left(2\right.$ units $\left.\mathrm{ml}^{-1}\right)$ was incubated with the Thiobacillus A2 membrane fraction $(0.5 \mathrm{mg}$ protein), horse heart cytochrome $c$ $(33 \mathrm{nmol})$ and thiosulphate $(1 \mu \mathrm{mol})$ no oxygen consumption occurred, indicating the soluble fraction to provide components as well as or other than rhodanese that were necessary for thiosulphate oxidation to occur. The addition of reduced lipoate resulted in rapid oxygen uptake even in the absence of rhodanese.

\section{Sulphite oxidation by cell-free preparations}

The rate of sulphite oxidation by the crude extract was negligible $\left[1.2-1.4 \mathrm{nmol} \mathrm{O} \mathrm{min}^{-1}(\mathrm{mg}\right.$ protein $)^{-1}$ ] in $0.05 \mathrm{M}$-phosphate buffer $\mathrm{pH} 7.4$ or $0.01 \mathrm{M}$-Tris $\mathrm{pH} 7 \cdot 4$. If horse heart cytochrome $c$ was added at 70 or $140 \mu \mathrm{M}$, the rate in $0.01 \mathrm{M}$-Tris was increased to 2.1 and 5.4 , respectively. In $0 \cdot 1 \mathrm{M}$-Tris $\mathrm{pH} 7 \cdot 4$, sulphite oxidation was increased to $5 \cdot 2$, and further stimulated to $13 \cdot 3$ by $70 \mu \mathrm{M}$-cytochrome $c$. The crude extract would oxidize $2 \mathrm{~mm}$-thiosulphate in phosphate buffer

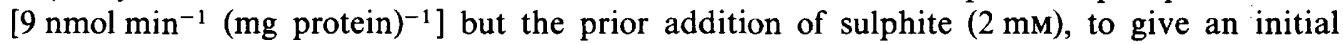
oxidation rate of $1.4 \mathrm{nmol} \mathrm{min}{ }^{-1}(\mathrm{mg} \text { protein) })^{-1}$ before thiosulphate addition, resulted in a rate of only 1.7 after adding thiosulphate.

Similarly, the oxygen uptake rate by the crude extracts was depressed by $40 \%$ when sulphite ( $2 \mathrm{mM})$ was added during thiosulphate oxidation. The inhibitory action of sulphite on thiosulphate-dependent oxygen uptake in phosphate buffer has not yet been explained, but is apparently not due to direct inhibition of cytochrome oxidase.

The soluble fraction $(130000 \mathrm{~g})$ had a very active sulphite:cytochrome $c$ oxidoreductase, exceeding that for thiosulphate by about 40 -fold. Sulphite-dependent cytochrome $c$ reduction could only be demonstrated in Tris buffer, as phosphate was markedly inhibitory. Thus the rate of reduction of cytochrome $c(35 \mu \mathrm{M})$ by sulphite $(1 \mathrm{mM})$ was $71 \mathrm{nmol} \mathrm{min}^{-1}$ (mg soluble protein $)^{-1}$ in $0.1 \mathrm{M}$-Tris $\mathrm{pH} 7.5$ but only 0.8 in $0.05 \mathrm{M}$-phosphate. Cytochrome $c$ reduction by thiosulphate had a $K_{\mathrm{m}}$ of about $200 \mu \mathrm{M}$-cytochrome $c$ and was consequently very slow in this system, but sulphite-dependent reduction was not affected by thiosulphate.

Ferricyanide was also reduced by sulphite using the soluble fraction. Respective rates were 65

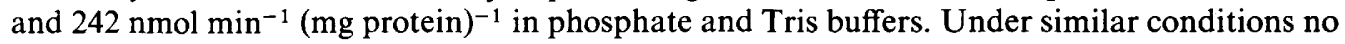
ferricyanide reduction was effected by thiosulphate.

\section{DISCUSSION}

This is the first time that a cell-free system from Thiobacillus A2 has been obtained that is capable of the stoicheiometric oxidation of thiosulphate to sulphate and the coupling of this to ATP synthesis. Recently Kula et al. (1982) reported unstable thiosulphate oxidizing activity in 
extracts of Thiobacillus A2 and a failure to observe ATP synthesis during thiosulphate oxidation. The data obtained are consistent with the following stoicheiometry:

$$
\mathrm{S}_{2} \mathrm{O}_{3}^{2-}+2 \mathrm{O}_{2}+\mathrm{H}_{2} \mathrm{O}+4 \mathrm{ADP}+4 \mathrm{P}_{\mathrm{i}}=2 \mathrm{SO}_{4}^{2-}+2 \mathrm{H}^{+}+4 \mathrm{ATP}
$$

The effects of the uncoupling agent 2,4-dinitrophenol and of electron transport inhibitors indicate that thiosulphate oxidation is coupled directly to cytochrome $c$ reduction, without involving cytochrome $b$ for the oxidation of either the sulphane- or sulphone-sulphur to sulphate, and that ATP synthesis is effected exclusively by electron transport phosphorylation coupled to the reoxidation of cytochrome $c$. The spectrophotometric observations with NADH, succinate and inhibitors showed that the organism contains a complete electron transport chain allowing electron flow from NADH to oxygen. The thiosulphate-oxidizing enzyme system was located in the 'soluble' $130000 \mathrm{~g}$ fraction of cell-free extracts and the membrane material was required only to provide the cytochrome oxidase system for terminal oxidation processes. This soluble fraction is currently being resolved in a search for enzymes catalysing thiosulphate cleavage and sulphane-sulphur or sulphite oxidation (W.P. Lu, unpublished data). It is noteworthy that the system obtained from Thiobacillus A2 is significantly different from that from $T$. novellus $(\mathrm{Oh} \&$ Suzuki, $1977 a, b)$ which was wholly membrane-associated. Among the enzymes believed by Suzuki (Suzuki, 1965; Suzuki \& Silver, 1966; Charles \& Suzuki, 1966; Oh \& Suzuki, 1977 a, b) to be involved in cell-free thiosulphate oxidation were rhodanese, sulphite oxidase and the 'sulphur-oxidizing enzyme'. The former were present in our preparations but our results give positive evidence incompatible with a role for a sulphur oxygenase in Thiobacillus A2. The demonstration that electrons from thiosulphate oxidation enter the electron transport chain at cytochrome $c$, and the $\mathrm{P} / \mathrm{O}$ of 1.0 , indicate that each pair of electrons transferred to oxygen supports one phosphorylation. Since four oxygen atoms (equivalent to four electron pairs) are consumed during thiosulphate oxidation and four ATP formed, all oxygen consumption must be used by cytochrome oxidase, and no oxygen could have been used in the direct oxygenation of sulphur.

Our results on thiosulphate-dependent phosphorylation using a $130000 \mathrm{~g}$ 'soluble' preparation can be compared with those of Cole \& Aleem (1970) using a $144000 \mathrm{~g}$ fraction from $T$. novellus. They believed their system to prove oxidative phosphorylation in a membrane-free soluble system. This is not the case with our data, as our observations indicate that membrane material, albeit very finely degraded, is present even after high-speed centrifuging. Moreover, high-speed supernatant preparations from lysozyme-treated bacteria are inactive, as no small membrane fragments are produced by this method in contrast to the French pressure cell or sonic disintegration methods.

The growth yield data obtained from the chemostat culture can be used for a theoretical comparison with the ATP synthesis observed with the cell-free systems. The 'true growth yield' $\left(Y_{\mathrm{S}_{2} \mathrm{O}_{3}^{2}}^{\max }\right.$ ) of 7.0 and carbon content of $46 \%$ of the dry weight indicates the fixation of $0.27 \mathrm{~mol} \mathrm{CO}_{2}$ for each thiosulphate oxidized. Since $\mathrm{CO}_{2}$-fixation by the Calvin cycle requires $3 \mathrm{ATP}$ and $2 \mathrm{NADH}$ for each $\mathrm{CO}_{2}$, a minimum of $0.81 \mathrm{ATP}$ and $0.54 \mathrm{NADH}$ must therefore be produced from the oxidation of one thiosulphate. As $0.54 \mathrm{NAD}^{+}$requires 1.08 reducing equivalents $(\mathrm{H})$ for reduction and thiosulphate oxidation produces $8 \mathrm{H}$ per mol oxidized, energy for the generation of ATP and cytochrome $c$-dependent reduction of $\mathrm{NAD}^{+}$comes from the oxidation with oxygen of $6.92 \mathrm{H}$ produced from $0.87 \mathrm{~mol}$ thiosulphate. ATP and NADH production from one mol thiosulphate oxidized for energetic purposes via electron transport to oxygen thus becomes 0.93 ATP $+0.62 \mathrm{NADH}$. Thiosulphate-dependent $\mathrm{NAD}^{+}$reduction in thiobacilli requires a minimum of 2 ATP per mol NAD ${ }^{+}$reduced (for reviews, see Kelly, 1978, 1982). Consequently the ATP required to effect the $\mathrm{CO}_{2}$-fixation required for the observed $Y_{\mathrm{S}_{2} \mathrm{O}_{2}^{2}}^{\mathrm{max}}$-would be 2.17 ATP per mol thiosulphate oxidized for energetic purposes. Since about $80 \%$ of the energy available from chemolithotrophic oxidations is probably expended directly in $\mathrm{CO}_{2}$ fixation and the remaining $20 \%$ in biosynthetic and transport processes, the total ATP production is indicated to be of the order of $2 \cdot 7$ ATP per mol thiosulphate. Experimentally the $\mathrm{P} / \mathrm{O}$ ratio of about one supported by cell-free thiosulphate oxidation indicated that the overall apparent efficiency of growth was lower than assumed in these calculations and could indicate 
that more than two ATP were consumed per mol NAD ${ }^{+}$reduced. The maximum experimental ATP production observed, of 4.4 per mol thiosulphate oxidized (Table 4 ), could indicate that 4 ATP were consumed for reduction of one $\mathrm{NAD}^{+}$. This problem is discussed in greater detail elsewhere (Kelly, 1982).

Thiobacillus A2 is proving the ideal experimental system for the elucidation of electron transport-dependent phosphorylation during sulphur compound oxidation as it is possible to obtain cell-free systems that are sufficiently stable for biochemical fractionation and are not complicated by the presence of any substrate-level phosphorylation, such as are present in some other thiobacilli (Kelly, 1982).

We are grateful for discussions and material assistance to Drs David Griffiths, Ezard Emanuel and Ann Wood. The work was made possible through financial support from the Government of the People's Republic of China, the British Council and the SERC.

\section{REFERENCES}

AleEm, M. I. H. (1965). Thiosulfate oxidation and electron transport in Thiobacillus novellus. Journal of Bacteriology 90, 95-101.

Charles, A. M. \& Suzuki, I. (1966). Mechanism of thiosulfate oxidation by Thiobacillus novellus. Biochimica et biophysica acta 128, 510-521.

Cole, J. S. \& Aleem, M. I. H. (1970). Oxidative phosphorylation in Thiobacillus novellus. Biochemical and Biophysical Research Communications 38, 736743.

KABACK, H. R. (1971). Bacterial membranes. Methods in Enzymology 22, 99-120.

KELlY, D. P. (1978). Bioenergetics of chemolithotrophic bacteria. In Companion to Microbiology, pp. 363-386. Edited by A. T. Bull \& P. M. Meadow. London: Longman.

KELLY, D. P. (1982). Biochemistry of the chemolithotrophic oxidation of inorganic sulphur. Philosophical Transactions of the Royal Society B298, 499-528.

Kelly, D. P., Chambers, L. A. \& Trudinger, P. A. (1969). Cyanolysis and spectrophotometric estimation of trithionate in mixture with thiosulfate and tetrathionate. Analytical Chemistry 41, 898-901.

Kula, T. J., Aleem, M. I. H. \& Wilson, D. F. (1982). Oxidation-reduction potentials of respiratory chain components in Thiobacillus A2. Biochimica et biophysica acta 680, 142-151

London, J. \& RitTenberG, S. C. (1964). Path of sulfur in sulfide and thiosulfate oxidation by thiobacilli. Proceedings of the National Academy of Sciences of the United States of America 52, 1183-1190.

Loya, S., YankofSKy, S. A. \& EPEL, B. L. (1982). Characterization of cytochromes in lithotrophically and organotrophically grown cells of Thiobacillus A2. Journal of General Microbiology 128, 2371-2378.

OH, J. K. \& SuZuKI, I. (1977a). Isolation and characterization of a membrane-associated thiosulphate-oxidizing system of Thiobacillus novellus. Journal of General Microbiology 99, 397-412.

OH, J. K. \& Suzuki, I. (1977b). Resolution of a membrane-associated thiosulphate-oxidizing com- plex of Thiobacillus novellus. Journal of General Microbiology 99, 413-423.

PECK, H. D. (1968). Energy metabolism in chemolithotrophic bacteria. Annual Review of Microbiology 22, $489-518$.

Robinson, J. \& COOPER, J. M. (1970). Method of determining oxygen concentrations in biological media, suitable for calibration of the oxygen electrode. Analytical Biochemistry 33, 390-399.

Ross, A. J., Schoenhoff, R. L. \& Aleem, M. I. H. (1968). Electron transport and coupled phosphorylation in the chemoautotroph Thiobacillus neapolitanus. Biochemical and Biophysical Research Communications 32, 301-306.

Silver, M. \& Kelly, D. P. (1976). Rhodanese from Thiobacillus A2: catalysis of reaction of thiosulphate with dihydrolipoate and dihydrolipoamide. Journal of General Microbiology 97, 277-284.

Söro, B. (1957). A colorimetric method for the determination of thiosulfate. Biochimica et biophysica acta 23, 412-416.

SuzuKI, I. (1965). Oxidation of elemental sulfur by an enzyme system of Thiobacillus thiooxidans. Biochimica et biophysica acta 104, 359-371.

SUZUKI, I. \& Silver, M. (1966). The initial product and properties of the sulphur-oxidizing enzyme of thiobacilli. Biochimica et biophysica acta 122, 22-23.

Tuovinen, O. H. \& Kelly, D. P. (1973). Studies on the growth of Thiobacillus ferrooxidans. Archit für Mikrobiologie 88, 285-298.

VANDENBERGH, P. A., BAWDON, R. E. \& BERK, R. S. (1979). Rapid test for determining the intracellular rhodanese activity of various bacteria. International Journal of Systematic Bacteriology 29, 339-344.

WoOD, A. P. \& KeLLY, D. P. (1977). Heterotrophic growth of Thiobacillus A2 on sugars and organic acids. Archices of Microbiology 113, 257-264.

Wood, A. P. \& Kelly, D. P. (1981). Mixotrophic growth of Thiobacillus A2 in chemostat culture on formate and glucose. Journal of General Microbiology 125, 55-62. 